\title{
KINERJA BIOREAKTOR HIBRID ANAEROB BERMEDIA TANDAN DAN PELEPAH SAWIT DALAM PENYISIHAN COD
}

\author{
Adrianto Ahmad*, Said Zul Amraini, Yance Andre Luturkey \\ Laboratorium Rekayasa Bioproses \\ Jurusan Teknik Kimia, Fakultas Teknik, Universitas Riau \\ Kampus BinaWidya, Jalan HR Subrantas Km 12,5 Panam Pekanbaru 28293 \\ Email: adri@unri.ac.id
}

\begin{abstract}
Abstrak
Kandungan Chemical Oxygen Demand (COD) yang tinggi dalam limbah cair pabrik minyak sawit dapat menyebabkan terhambatnya kontak antara udara dengan badan air penerima sehingga mengakibatkan berkurangnya kelarutan oksigen dalam badan air penerima tersebut. Oleh karena itu, penting dilakukan terobosan baru untuk mendapatkan teknologi pengolahan limbah cair yang handal agar kandungan COD menjadi rendah. Salah satu teknologi pengolahan limbah cair tersebut adalah bioreaktor hibrid anaerob. Penelitian ini bertujuan mengkaji kinerja beberapa jenis bioreaktor hibrid anaerob dalam penyisihan COD dalam limbah cair pabrik minyak sawit. Pada penelitian ini digunakan dua unit bioreaktor yakni bioreaktor hibrid anaerob dengan media imobilisasi sel tandan kosong sawit dan bioreaktor hibrid anaerob dengan media imobilisasi sel pelepah sawit dengan volume kerja $2,5 \mathrm{~m}^{3}$. Proses pengolahan dilakukan dengan variasi laju pembebanan zat organik, yaitu10; 12,$5 ; 14,28 ; 16,6 ; 20 ; 25 ; 33,3 ; 50 \mathrm{~kg} \mathrm{COD} / \mathrm{m}^{3}$ hari. Hasil penelitian menunjukkan bahwa penyisihan COD yang tertinggi dicapai sebesar $82,67 \%$ dengan laju pembebanan organik $14,28 \mathrm{~kg} \mathrm{COD} / \mathrm{m}^{3}$ hari pada bioreaktor bermedia tandan kosong sawit dan $84 \%$ untuk laju pembebanan organik 16,6 kg COD/ $\mathrm{m}^{3}$ hari pada bioreaktor bermedia pelepah sawit. Dengan demikian, kedua bioreaktor hibrid anaerob ini dapat digunakan untuk mengolah limbah cair industri minyak sawit dengan beban COD tinggi.
\end{abstract}

Kata kunci: bioreaktor hibrid, COD, limbah cair, pelepah sawit, tandan kosong sawit

\begin{abstract}
The high contents of Chemical Oxygen Demand (COD) in palm oil mill wastewater is able to cause the obstructed connection between air and a receiver of water body so that can make the lessening oxygen solubility in the receiver of water body. Hence, it is important to do innovation to get a good technology process of wastewater in order that the contents of COD become low. One of the wastewater processes can be done by using hybrid anaerobic bioreactor in eliminating COD that exists in palm oil mill wastewater. This research uses two units of hybrid anaerobic bioreactor i.e. hybrid anaerobic bioreactor mediated immobilization cell of empty stem palm and hybrid anaerobic bioreactor mediated immobilization cell of in $2.5 \mathrm{~m}^{3}$ of work volume. The process is done by using variation of imposition organic rate i.e. $10,12.5,14.28,16.6,20,25,33.3$, and $50 \mathrm{~kg} \mathrm{COD} / \mathrm{m}^{3}$-day. The result of research showed that the highest eliminating COD is $82.67 \%$ in $14.28 \mathrm{~kg} \mathrm{COD} / \mathrm{m}^{3}$ day in bioreactor filled with empty palm fruit bunch and $84 \%$ for imposition organic rate $16.6 \mathrm{~kg} \mathrm{COD} / \mathrm{m}^{3}$-day in bioreactor filled with palm midrib. Therefore, both hybrid anaerobic bioreactors can be used for processing oil palm mill wastewater in high load of COD.
\end{abstract}

Keywords: hybrid bioreactor, COD, wastewater, palm midrib, empty stem palm 


\section{Pendahuluan}

Pengembangan pabrik minyak sawit mempunyai dampak positif dan dampak negatif bagi masyarakat. Sebagai dampak positif, pabrik minyak sawit merupakan salah satu sumber penghasil devisa yang sangat potensial bagi Indonesia. Pabrik minyak sawit berhasil menyumbang devisa negara sebesar US\$ 13,79 miliar per tahun dan Indonesia merupakan salah satu produsen minyak sawit mentah terbesar di dunia dengan jumlah produksi sebesar 50,2\% dari total produksi minyak sawit dunia (Dradjat, 2007), sedangkan dampak negatifnya adalah semakin tinggi jumlah produksi minyak sawit menyebabkan limbah cair yang dihasilkan juga akan semakin tinggi.

Limbah cair pabrik minyak sawit tersebut akan mencemari lingkungan sekitarnya, terutama lingkungan perairan karena limbah cair tersebut mengandung senyawa organik yang sangat tinggi. Kandungan senyawa organik tersebut ditunjukkan dengan tingginya nilai Chemical Oxygen Demand (COD) yang berkisar antara 40.000-120.000 mg/L (Irfan, 2008), sedangkan nilai baku mutu yang ditetapkan oleh pemerintah melalui Keputusan Menteri Negara Lingkungan Hidup Nomor: Kep51/MENLH/10/1995 adalah $350 \mathrm{mg} / \mathrm{L}$ untuk COD dan $100 \mathrm{mg} / \mathrm{L}$ untuk BOD.

Penanganan limbah cair minyak sawit dapat dilakukan secara biologi yaitu menggunakan proses anaerob (Malia, 2009). Proses anaerob merupakan proses biodegradasi senyawa organik kompleks menjadi gas metan dan $\mathrm{CO}_{2}$ dalam kondisi tanpa adanya oksigen. Proses anaerob melibatkan beberapa tahap proses yaitu proses hidrolisis, proses asidogenesis, proses asetogenesis dan proses metanogenesis (Ahmad, 2004). Salah satu alternatif teknologi penanganan limbah cair tersebut adalah bioreaktor hibrid anaerob.

Bioreaktor hibrid anaerob yang digunakan merupakan penggabungan antara sistem pertumbuhan mikroorganime tersuspensi dan pertumbuhan melekat. Pada sistem pertumbuhan tersuspensi (suspended growth), mikroorganisme tumbuh dan berkembang dalam keadaan tersuspensi di dalam fasa cair, sedangkan di dalam sistem pertumbuhan melekat (attached growth), mikroorganisme tumbuh dan berkembang dengan melekat di permukaan media pendukung dengan membentuk lapisan biofilm (Ahmad, 2009). Media pendukung yang digunakan pada penelitian ini adalah tandan kosong sawit dan pelepah sawit. Tandan kosong dan pelepah sawit dipilih karena mudah didapat, memiliki permukaan kasar dan luas permukaan per volume yang besar. Makalah ini bertujuan untuk mengkaji kinerja masing-masing bioreaktor hibrid anaerob dalam menyisihkan COD limbah cair pabrik minyak sawit.

\section{Metodologi}

Metode penelitian yang akan dijelaskan di bawah ini meliputi sumber limbah cair, rancangan bioreaktor, start-up bioreaktor, parameter yang diamati dan metoda analisa.

\subsection{Sumber Limbah Cair}

Limbah cair yang digunakan dalam penelitian ini berasal dari limbah cair pabrik minyak sawit PTPN V Sei.Pagar, Kabupaten Kampar Propinsi Riau. Karakteristik limbah cair tersebut ditampilkan pada Tabel 1.

Tabel 1. Karakteristik Limbah Cair Minyak Sawit PTPN V Sei. Pagar

\begin{tabular}{cll}
\hline Parameter & Satuan & Nilai \\
\hline $\mathrm{pH}$ & - & 5,6 \\
$(\mathrm{COD})$ & $\mathrm{mg} / \mathrm{L}$ & 50.000 \\
\hline
\end{tabular}

\subsection{Rancangan Bioreaktor}

Pada penelitian ini digunakan 2 unit bioreaktor hibrid anaerob dengan volume kerja masing-masing sebesar 2,5 $\mathrm{m}^{3}$ yang terdiri dari bagian bersekat dengan volume kerja $1 \mathrm{~m}^{3}$ dan bagian yang tidak bersekat dengan volume kerja 1,5 $\mathrm{m}^{3}$. Pada bagian yang tidak bersekat dimasukkan pelepah sawit dalam bioreaktor hibrid A dan tandan kosong sawit dalam bioreaktor hibrid B sebanyak \pm 250 kg sebagai media imobilisasi sel mikroorganisme. Secara skematis bioreaktor hibrid anaerob yang digunakan ditampilkan pada Gambar 1.

Dari Gambar 1 dapat dijelaskan bahwa, limbah cair yang akan diolah, dimasukkan kedalam tangki influen. Kemudian, dengan menggunakan pompa, limbah cair tersebut dialirkan kedalam bioreaktor dengan mengontrol bukaan valve sesuai dengan beban organik yang diinginkan. Pola aliran limbah cair pabrik minyak sawit di dalam bioreaktor adalah turun dan naik mengikuti sekat yang ada di dalam bioreaktor hibrid anaerob dan pada akhirnya aliran akan keluar menuju tangki keluaran. Pada bagian atas bioreaktor hibrid anaerob tersebut dilengkapi dengan pipa dan selang untuk mengalirkan gas ke tangki penampungan biogas. 


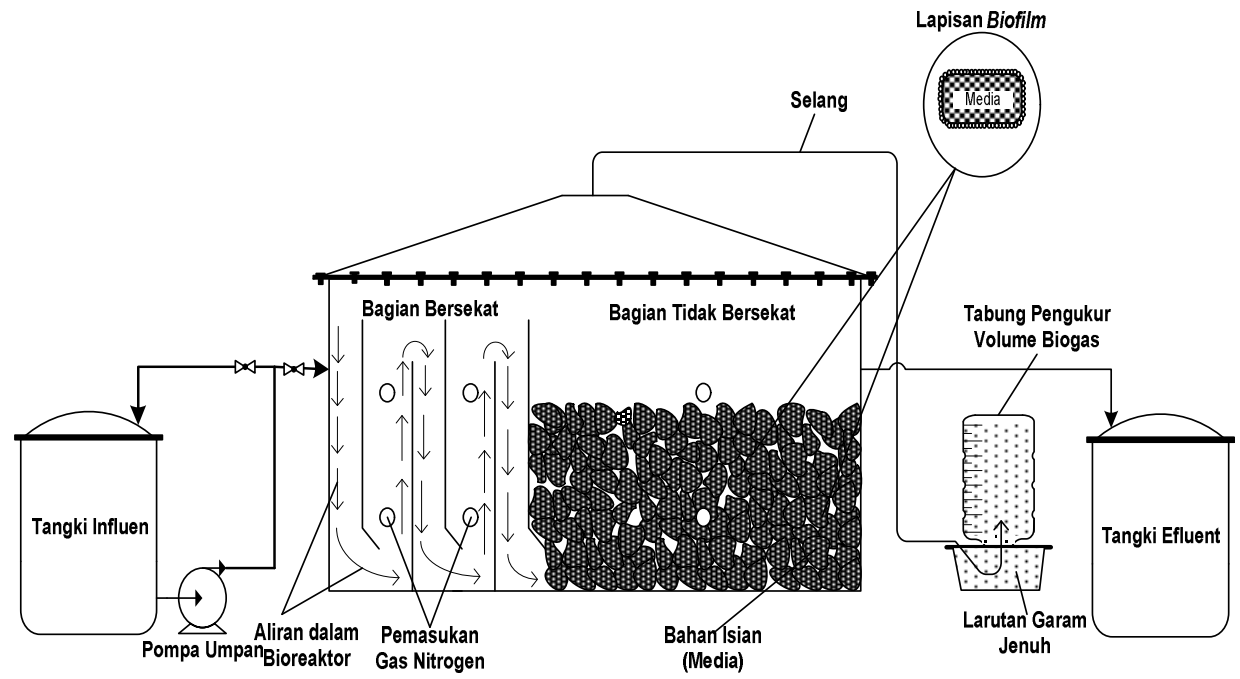

Gambar 1. Set-up alat bioreaktor hibrid anaerob

\subsection{Start-up Bioreaktor}

Start-up bioreaktor dilakukan dengan cara memasukkan lumpur kolam 2 (kolam asidogenesis) Instalasi Pengolahan Air Limbah (IPAL) PTPN V Sei. Pagar sebanyak 1 $\mathrm{m}^{3}$ dibagian ruang yang bersekat dan lumpur kolam 4 (kolam metanogenesis) Instalasi Pengolahan Air Limbah (IPAL) PTPN V Sei. Pagar sebanyak 1,5 $\mathrm{m}^{3}$ pada bagian ruang tidak bersekat sebagai bibit mikroorganisme. Setelah itu, diumpankan limbah cair keluaran kolam 1 (kolam deolisasi) dengan laju pembebanan organik $10 \mathrm{kgCOD} / \mathrm{m}^{3}$ hari. Proses start-up bioreaktor berlangsung pada suhu ruang dan pH 6,8-7,4 hingga tercapai keadaan tunak.

\subsection{Variabel Penelitian}

Variabel proses yang digunakan dalam penelitian ini adalah laju pembebanan organik sebesar $10 ; 12,5 ; 14,3 ; 16,6 ; 20 ; 25 ; 33,3$ dan $50 \mathrm{~kg}$ COD $/ \mathrm{m}^{3}$ hari. Parameter yang diamati antara lain mencakup $\mathrm{pH}$, temperatur dan nilai COD. Analisa COD dilakukan sesuai dengan Standard Methods for the Examination of Water and Wastewater (Eaton dkk., 1992). Pengambilan sampel dilakukan setiap hari pada influen dan keluaran bioreaktor hibrid anaerob dan pengujian dilakukan secara duplo.

\section{Hasil dan Pembahasan}

Pada bagian ini akan ditampilkan pengamatan pada proses start-up dan proses tunak bioreaktor hibrid anaerob. Hasil pengamatan ditampilkan dengan membahas hubungan antara waktu start-up terhadap perubahan $\mathrm{pH}$, temperatur, nilai COD pada masing-masing bioreaktor dan pada kondisi tunak dibahas hubungan antara pembebanan organik terhadap nilai COD.

\subsection{Proses Start-up Bioreaktor}

3.1.1 Perubahan pH selama Start-up Bioreaktor Hibrid Anaerob

Perubahan nilai $\mathrm{pH}$ selama proses start-up ditampilkan dalam Gambar 2. Gambar 2 menunjukkan bahwa pada awal pengukuran $\mathrm{pH}$, diperoleh $\mathrm{pH}$ limbah cair sebesar 5,6. Namun pada hari pertama proses start-up, $\mathrm{pH}$ sistem meningkat menjadi 6,3 untuk bioreaktor dengan media tandan kosong sawit dan menjadi 6,4 untuk bioreaktor dengan media pelepah sawit. Perubahan $\mathrm{pH}$ sistem relatif konstan setelah hari ke-19 proses startup bioreaktor yaitu berkisar antara 7,8-8,1. Pada rentang $\mathrm{pH}$ tersebut, mikroorganisme anaerob di dalam bioreaktor dapat berkembang-biak dengan optimal karena kondisi lingkungan mikroorganisme anaerob yang optimum berkisar pada $\mathrm{pH}$ antara 5,88,2 (Ahmad, 2004).

\subsubsection{Perubahan Temperatur selama Start- up Bioreaktor Hibrid Anaerob}

Profil temperatur sistem selama proses start-up bioreaktor hibrid anaerob ditampilkan dalam Gambar 3. Gambar menunjukkan bahwa temperatur sistem pengolahan limbah cair dengan menggunakan bioreaktor hibrid anaerob berkisar antara 30$32{ }^{\circ} \mathrm{C}$. Pada rentang temperatur tersebut menunjukkan bahwa komunitas mikroorganisme yang terdapat dalam sistem bioreaktor hibrid anaerob adalah komunitas mikroorganisme mesofilik dengan 
pertumbuhan optimum pada temperatur 10$50^{\circ} \mathrm{C} \quad$ (Manurung, 2004). Komunitas mikroorganisme mesofilik sangat baik digunakan di dalam pengolahan limbah cair indusri, karena pada rentang temperatur tersebut pertumbuhan mikroorganisme mesofilik tidak membutuhkan penambahan energi dari luar untuk mengatur temperatur proses, sehingga dinilai lebih hemat dan ekonomis (Ahmad, 2009).

\subsubsection{Perubahan Nilai COD Keluaran selama Start-up Bioreaktor Hibrid Anaerob \\ Profil nilai COD keluaran pada} bioreaktor hibrid anaerob dengan media imobilisasi sel yang berbeda ditampilkan pada Gambar 4. Nilai COD merupakan indikator pencemaran air oleh zat-zat organik yang terkandung dalam limbah cair. Gambar 4 menunjukkan bahwa perubahan nilai COD untuk bioreaktor hibrid bermedia tandan kosong sawit dan bioreaktor hibrid bermedia pelepah sawit cenderung mengalami penurunan selama proses start-up. Untuk bioreaktor hibrid bermedia tandan kosong sawit, nilai COD menurun dari $40.000 \mathrm{mg} / \mathrm{L}$ menjadi $10.000 \mathrm{mg} / \mathrm{L}$ dan untuk bioreaktor hibrid bermedia pelepah sawit, nilai COD menurun dari $35.000 \mathrm{mg} / \mathrm{L}$ menjadi 10.000 $\mathrm{mg} / \mathrm{L}$. Penurunan COD yang tinggi ini membuktikan bahwa mikroorganisme anaerob mempunyai aktivitas yang tinggi dalam mendegradasi limbah cair pabrik minyak sawit.Proses start-up dapat dianggap telah selesai apabila kondisi tunak (steady state) telah tercapai dengan indikator fluktuasi nilai COD sebesar 10\%. Bioreaktor hibrid bermedia tandan kosong sawit menunjukkan bahwa fluktuasi nilai COD $10 \%$ pada hari ke-29, ke-30, dan ke-31, yaitu sebesar $20.000 \mathrm{mg} / \mathrm{L}, 10.000 \mathrm{mg} / \mathrm{L}$ dan $10.000 \mathrm{mg} / \mathrm{L}$ serta efisiensi penyisihan COD yang dicapai yaitu sebesar 73,33\%, sedangkan untuk bioreaktor hibrid bermedia pelepah sawit, nilai COD pada hari ke-30, ke-31, dan ke-32 menunjukkan fluktuasi $10 \%$, yaitu sebesar $15.000 \mathrm{mg} / \mathrm{L}, 10.000 \mathrm{mg} / \mathrm{L}$ dan $10.000 \mathrm{mg} / \mathrm{L}$ serta efisiensi penyisihan COD yang dicapai yaitu sebesar 76,67\%. Dengan demikian, proses start-up bioreaktor hibrid anaerob berlangsung selama 31 hari.



Gambar 2. Profil pH selama start-up bioreaktor hibrid anaerob pada laju pembebanan organik $10 \mathrm{~kg}$ COD $/ \mathrm{m}^{3}$ hari

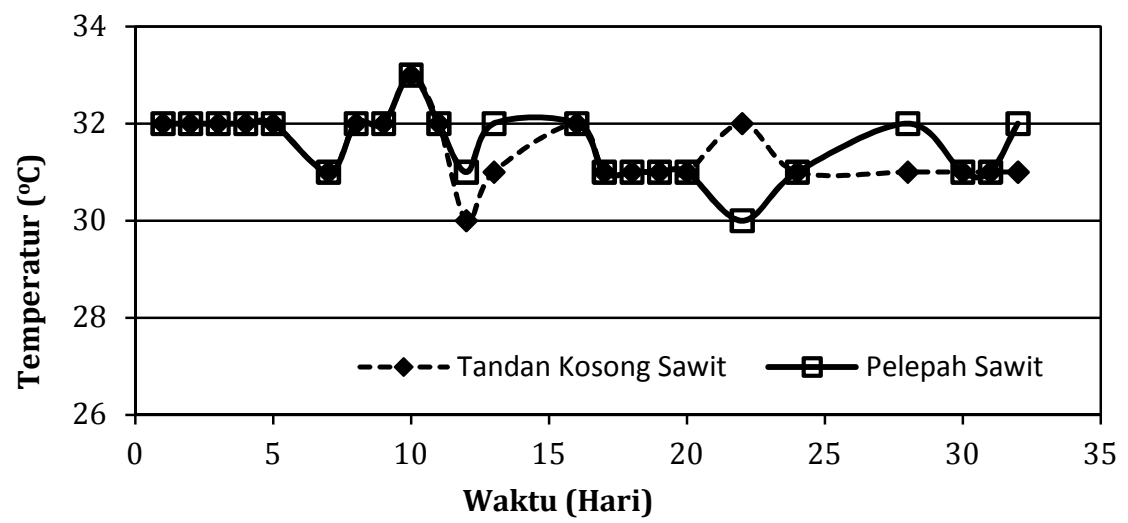

Gambar 3. Profil temperatur selama start-up bioreaktor hibrid anaerob pada laju pembebanan organik $10 \mathrm{~kg}$ COD $/ \mathrm{m}^{3} \mathrm{hari}$ 




Gambar 4. Profil nilai COD keluaran pada bioreaktor hibrid anaerob pada laju pembebanan organik $10 \mathrm{~kg}$ COD $/ \mathrm{m}^{3}$ hari

3.2 Kondisi Tunak

3.2.1 Nilai COD Keluaran dan Efisiensi Penyisihan COD

Setelah keadaan tunak tercapai, pengolahan dilanjutkan dengan variasi laju pembebanan organik sebesar $10 ; 12,5 ; 14,28$;
16,6; 20; 25; 33,34 dan $50 \mathrm{~kg} \mathrm{COD} / \mathrm{m}^{3}$ hari. Hubungan antara beban organik terhadap nilai COD keluaran dan efisiensi penyisihan COD ditampilkan pada Gambar 5 dan Gambar 6.

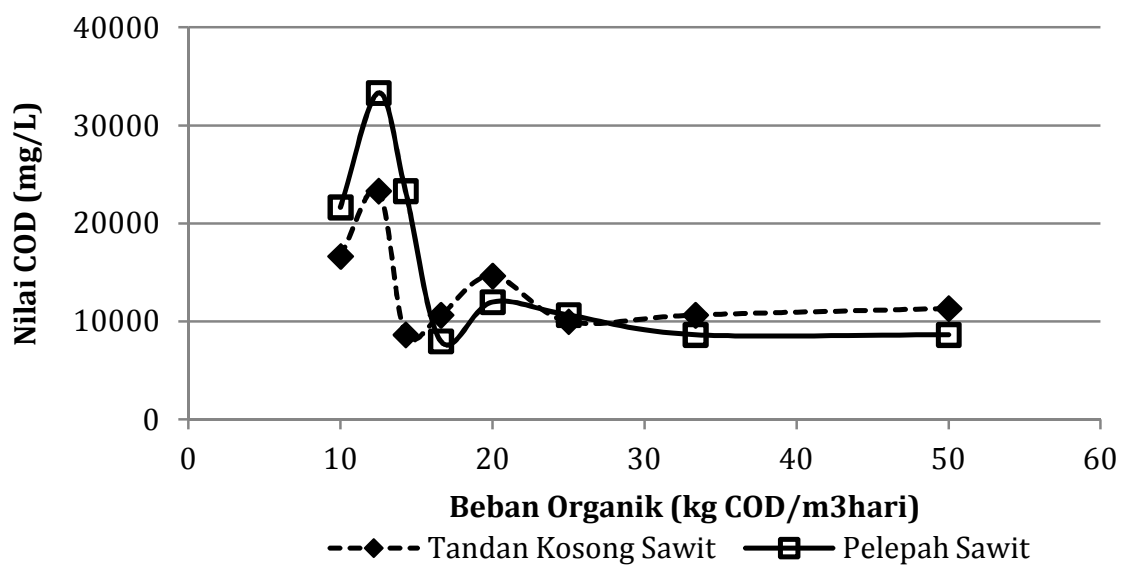

Gambar 5. Hubungan antara beban organik terhadap nilai COD keluaran

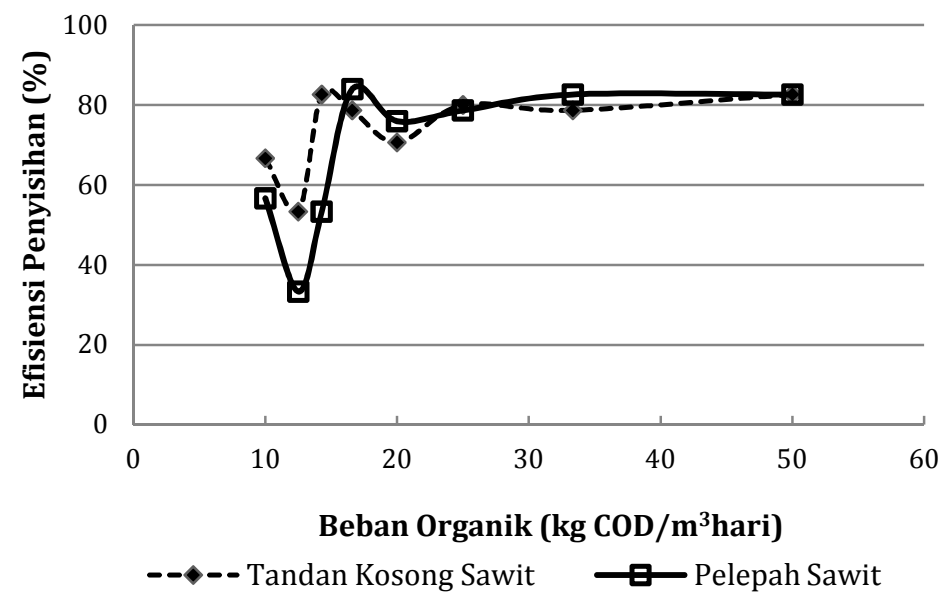

Gambar 6. Hubungan antara beban organik terhadap efisiensi penyisihan COD keluaran 
Hasil yang diperoleh tersebut di atas menunjukkan bahwa kemampuan bioreaktor hibrid bermedia pelepah sawit dalam mendegradasi senyawa organik yang terdapat pada limbah cair pabrik minyak sawit relatif lebih tinggi daripada bioreaktor hibrid bermedia tandan kosong sawit. Relatif tingginya proses biodegradasi senyawa organik pada bioreaktor bermedia pelepah sawit disebabkan karena struktur pelepah sawit jauh lebih kuat dibandingkan tandan kosong sawit (Ditjen PPHP, 2006), sehingga pertumbuhan melekat mikroorganisme jauh lebih baik pada media pelepah sawit. Selain itu, tandan kosong sawit lebih mudah hancur karena kandungan seratnya yang sangat tinggi (Ditjen PPHP, 2006), sehingga tidak cukup kuat untuk menjadi media pertumbuhan melekat mikroorganisme. Namun demikian, kinerja kedua unit bioreaktor hibrid anaerob tersebut, baik bioreaktor bermedia tandan kosong sawit, maupun bioreaktor bermedia pelepah sawit tidak berbeda secara signifikan.

\subsubsection{Komparatif Kinerja Bioreaktor Hibrid Anaerob}

Studi komparatif kinerja bioreaktor hibrid anaerob ditinjau dengan membandingkan kinerja bioreaktor hibrid anaerob terhadap bioreaktor anaerob lainnya dalam mengolah limbah cair industri. Perbandingan kinerja bioreaktor hibrid anaerob dengan bioreaktor lainnya disajikan dalam Tabel 2.

Tabel 2 menunjukkan bahwa baik bioreaktor hibrid bermedia tandan kosong sawit maupun bioreaktor hibrid bermedia pelepah sawit ini memiliki efisiensi penyisihan COD yang relatif tinggi dan relatif sama dengan beberapa bioreaktor lain. Hal ini dapat dicapai karena bioreaktor hibrid anaerob ini merupakan penggabungan sistem pertumbuhan mikroorganisme tersuspensi dan melekat, sehingga memiliki kelebihan dalam mempertahankan konsentrasi biomassa dalam jumlah yang tinggi sehingga efisiensi penyisihan senyawa organik menjadi lebih besar (Syafila, 2003).

\section{Kesimpulan}

Proses start-up bioreaktor hibrid anaerob bermedia tandan kosong dan pelepah sawit berlangsung selama 31 hari dengan efisiensi penyisihan COD $73,3 \%$ pada bioreaktor hibrid bermedia tandan kosong dan $76,7 \%$ pada bioreaktor hibrid bermedia pelepah sawit. Pada kondisi tunak, efisiensi penyisihan COD tertinggi pada bioreaktor hibrid anaerob bermedia tandan kosong sawit dicapai pada pembebanan organik 14,28 kg $\mathrm{COD} / \mathrm{m}^{3}$ hari yaitu sebesar $82,6 \%$. Pada kondisi tunak, efisiensi penyisihan COD tertinggi pada bioreaktor hibrid anaerob bermedia pelepah sawit dicapai pada pembebanan organik $16,6 \mathrm{kgCOD} / \mathrm{m}^{3}$ hari yaitu sebesar $84 \%$. Dengan demikian bioreaktor hibrid anaerob bermedia pelepah sawit dan tandan kosong sawit ini dapat dijadikan sebagai salah satu alternatif dalam penanganan limbah cair pabrik minyak sawit.

\section{Ucapan Terima Kasih}

Penulis mengucapkan terima kasih kepada Pemerintah Republik Indonesia yang telah membiayai penelitian ini melalui Program Hibah Kompetitif Penelitian Unggulan Strategis Nasional Batch I Tahun 2009 dengan surat perjanjian Pelaksanaan Penelitian No. 428/SP2H/PP/DP2M/6/2009 tanggal 20 Juni 2009.

Tabel 2. Perbandingan Kinerja Bioreaktor Hibrid Anaerob dengan Bioreaktor Anaerob Lainnya

\begin{tabular}{lccl}
\hline \multicolumn{1}{c}{ Jenis Bioreaktor } & Limbah & $\begin{array}{c}\text { Efisiensi } \\
\text { Penyisihan COD } \\
\text { (\%) }\end{array}$ & Pustaka \\
\hline Bioreaktor UASB & Pangan & 82,90 & $\begin{array}{l}\text { Nugrahini, } \\
2008\end{array}$ \\
Anaerobic digestion & Tapioka & 82,84 & $\begin{array}{l}\text { Widjaja dkk., } \\
2008\end{array}$ \\
$\begin{array}{l}\text { Bioreaktor hibrid bermedia } \\
\text { pelepah sawit }\end{array}$ & Minyak Sawit & 84,00 & Penelitian ini \\
$\begin{array}{l}\text { Bioreaktor hibrid tandan } \\
\text { kosong sawit }\end{array}$ & Minyak Sawit & 82,60 & Penelitian ini \\
\hline Keterangan: UASB = Upflow Anaerobic Sludge Blanket & &
\end{tabular}

Keterangan: UASB $=$ Upflow Anaerobic Sludge Blanket 


\section{Daftar Pustaka}

Dradjat, B., Perkebunan kelapa sawit indonesia masih berpotensi dikembangkan, Warta Penelitian dan Pengembangan Pertanian, 2007, 29(2), 6-7.

Irfan, M., Pengolahan Limbah Cair Pabrik Kelapa Sawit dengan Land Application System di PT. Perkebunan Nusantara V Sei. Pagar, Laporan Kerja Praktek, Universitas Riau, 2008.

Malia, F., Peranan Mikroorganisme Tersuspensi dan Terlekat di Fase Terlekat pada Bioreaktor Hibrid Upflow Anaerob Menggunakan Media Bambu untuk Biodegradasi Molase dengan Pengaruh Pembebanan Organik dan Waktu Detensi, Tesis, Institut Teknologi Bandung, 2009.

Ahmad, A., Studi komparatif sumber dan proses aklimatisasi bakteri anaerob pada limbah cair yang mengandung karbohidrat, protein dan minyak-lemak, Jurnal Sains dan Teknologi, 2004, 3(1), 1-10.

Ahmad, A., Dasar-dasar Teknologi Pengolahan Limbah Cair Industri, Diktat Kuliah, Universitas Riau, 2009.

Eaton, A. D.; Greenberg, A. E.; Clesceri, L. S.; Franson, M. A. H., Standard Methods for the Examination of Water and Wastewater, American Public Health Association: Washington DC, 1992.
Manurung, R., 2004, Proses Anaerobik sebagai Alternatif untuk Mengolah Limbah Sawit, eUSU Repository (http://library.usu.ac.id/ download/ft/tkimia-renita.pdf), Universitas Sumatera Utara, 2004.

Nugrahini, P.; Habibi, T. M. R.; Safitri, A. D., Penentuan Parameter Kinetika Proses Anaerobik Campuran Limbah Cair Industri Menggunakan Reaktor Upflow Anaerobic Sludge Blanket (UASB), Prosiding Seminar Nasional Sains dan Teknologi-II 2008, Bandarlampung, 17-18 November 2008, hal. III 521.

Syafila, M.; Djajadiningrat, A. H.; Handajani, M., Kinerja bioreaktor hibrid anaerob dengan media batu untuk pengolahan air buangan yang mengandung molase, Prosiding ITB Sains \& Teknologi, 2003, 35A(1), 19-31.

Ditjen PPHP, Pedoman Pengelolaan Limbah Industri Kelapa Sawit, Subdit Pengelolaan Lingkungan Direktorat Pengolahan Hasil Pertanian, Departemen Pertanian, 2006.

Widjaja, T.; Altway, A.; Prameswarhi, P.; Wattimena, F. S., Pengaruh HRT dan Beban COD Terhadap Pembentukan Gas Methan pada Proses Anaerobic Digestion Menggunakan Limbah Padat Tepung Tapioka, Prosiding Seminar Nasional Soebardjo Brotohardjono, Surabaya, 18 Juni 2008, hal. B6 1-6. 